\title{
THE DEFENCE OF ALL REASONABLE CARE
}

... even a dog knows the difference between being kicked and being stumbled over. ${ }^{1}$

\section{CANADIAN AUTHORITY}

Prior to May 1978, there was no clear Canadian authority recognizing the existence of a defence of all reasonable care. For some offences it was necessary that the Crown prove affirmatively beyond a reasonable doubt a mens rea, that is, an intent to commit the offence. For other offences, sometimes called offences of strict or absolute liability, the Crown did not have to prove mens rea, but merely the actus reus. There was no sure and certain method of determining whether an offence was in the first category or the second. ${ }^{2}$ For example, in $R$. v. Pierce Fisheries ${ }^{3}$ the Supreme Court of Canada decided that mens rea or proof of knowledge was not required to convict on a charge of having possession of undersized lobsters contrary to regulations made pursuant to the Fisheries Act, R.S.C. 1952, c. 119. But the same court decided that possession of a drug without knowing what it was is no offence. ${ }^{4}$

In May 1978, the Supreme Court of Canada, with Dickson J. writing for a unanimous court, clearly defined a new category of strict liability offences. This new category does not require the Crown to prove mens rea beyond a reasonable doubt. It allows the defendant to exculpate himself by showing on a balance of probabilities that he took all reasonable care to avoid committing the offence. ${ }^{5}$

\section{A. $R$. v. The City of Sault Ste. Marie}

\section{The Facts}

The City of Sault Ste. Marie was charged under 8. 32(1) of the Ontario Water Resources Act, R.S.O. 1970, c. 332, which provides:

32(1) Every municipality or person that discharges or deposits or causes or permits the discharge or deposit of any material of any kind into or in any well, lake, river, pond, spring, stream, reservoir or other water or watercourse or on any shore or bank thereof or into or any place that may impair the quality of the water of any well, lake, river, pond, spring, stream, reservoir or other water or watercourse is guilty of an offence and on summary conviction is liable on first conviction to a fine of not more than $\$ 5,000$ and on each subsequent conviction to a fine of not more than $\$ 10,000$ or to imprisonment for a term of not more than one year, or to both such fine and imprisonment.

The City had entered into a contract with Cherokee Disposal and Construction Company for the disposal of all refuse originating in the city, whereby the company was to furnish a site and all labour, material and equipment. Cherokee was prosecuted separately for the same incidents which give rise to the present case and was convicted by Greco, Provincial Court Judge, under the same section of the Water Resources Act. ${ }^{6}$ The question in the case under discussion here was whether the city was also guilty of an offence under this section.

1. Studies on Strict Liability, Law Reform Commission of Canada, 1974, at 175.

2. Law Reform Commission of Canada, Studies on Strict Liability (1974), 171.

3. $R$. v. Pierce Fisheries [1970] 5 C.C.C. 193, 12 D.L.R. (3d) 591, [1971] S.C.R. 5, 12 C.R.N.S. 272.

4. Beaver v. The Queen [1957] S.C.R. 531.

5. $R$. v. City of Sault Ste. Marie (1978) 40 C.C.C. (2d) 353 (S.C.C.).

6. $R$. v. Cherokee Disposals \& Construction Ltd. [1973] 3 O.R. 599 (Ont. Prov. Ct.). 
The Supreme Court of Canada was the fifth court to consider this charge. The Provincial Court of Ontario, Criminal Division, acquitted the City. The Crown appealed, and on a trial de novo, the City was convicted. The City then appealed to the Divisional Court, where the conviction was quashed; in a further appeal, the Ontario Court of Appeal directed a new trial. Both the Crown and the City were granted leave to appeal to the Supreme Court of Canada.

\section{The Three Categories}

In sending this case back for a new trial, the Supreme Court of Canada, with Dickson J. writing for the full court, held that there are now three categories of offences rather than the traditional two:?

(1) Offences in which mens rea, consisting of some positive state of mind such as intent, knowledge, or recklessness, must be proved by the prosecution either as an inference from the nature of the act committed, or by additional evidence.

(2) Offences in which there is no necessity for the prosecution to prove the existence of mens rea; the doing of the prohibited act prima facie imports the offence, leaving it open to the accused to avoid liability by proving that he took all reasonable care. This involves consideration of what a reasonable man would have done in the circumstances. The defence will be available if the accused reasonably believed in a mistaken set of facts which, if true, would render the act or omission innocent, or if he took all reasonable steps to avoid the particular event. These offences may properly be called offences of strict liability.

(3) Offences of absolute liability where it is not open to the accused to exculpate himself by showing that he was free of fault.

\section{(a) Full Mens Rea: Dickson's First Category}

This category includes offences in which mens rea, consisting of some positive state of mind such as intent, knowledge, or recklessness, must be proved by the prosecution either as an inference from the nature of the act committed, or by additional evidence. Offences which are criminal in the true sense would be included in this category. But Dickson $J$. notes that since criminal law is federal, provincial legislation cannot create an offence which is criminal in the true sense, such as to give rise to the presumption of full mens rea. If the province wants to create an offence giving rise to full mens rea, it would arguably have to use words like "wilfully", "with intent", "knowingly", or "intentionally" in its statutes.

\section{(b) Absolute Liability: Dickson's Third Category}

Included in this category are offences of absolute liability where it is not open to the accused to exculpate himself by showing that he was free of fault. Dickson J. states ${ }^{8}$ that offences of absolute liability would be those in respect of which the legislature had made it clear that guilt would follow proof merely of the proscribed act. To determine the intent of the Legislature, one would look at the overall regulatory pattern adopted by the Legislature, the subject matter, importance of the penalty, and precision of language used.

Traditionally, public welfare offences have been held to be offences of absolute liability, for reasons which Dickson J. considers. Common arguments in favour of absolute liability in these offences include:

1. Where protection of social interests is involved, a high standard of care is required, and the incentive to take this care is provided by the knowledge that no excuses or loopholes exist as a defence. 
2. Administrative efficiency demands that the Crown not be required to prove mens rea beyond a reasonable doubt for the multitude of offences involved.

3. In further rationalization, it is said that a finding of guilt does not carry the stigma associated with conviction for a criminal offence.

Dickson J. refutes these arguments and provides others against absolute liability: ${ }^{9}$

1. There is no evidence that the high standard of care results from absolute liability; in fact, the opposite may be the result, since the person may know that in the event of breach, no evidence of care and skill can serve as a defence.

2. The administrative efficiency argument may be met by shifting the burden to the defendant to show all reasonable care, once the Crown has established the actus reus. Evidence of due diligence is admissible for sentencing purposes and therefore might just as well be heard for purposes of assessing guilt.

3. Public interest is no more involved here than in serious crimeswhere mens rea must be proved.

4. Absolute liability violates fundamental principles of penal liability.

5. The accused suffers loss of time, legal costs, exposure to the processes of the criminal law at trial, and conviction; thus the argument that no stigma attaches does not withstand analysis. Penalties may involve heavy fines and even imprisonment.

(c) The Middle Ground

Under the new middle ground, the Crown still must prove the actus reus beyond a reasonable doubt. Once the Crown proves the actus reus, prima facie the offence has been committed. Then the burden shifts to the defendant to avoid liability by proving on a balance of probabilities that he took all reasonable care. The test of reasonable care set out by Dickson $J$. encompasses situations where the defendant did not know the facts but took all reasonable care to find out, and also the situations where he does know the facts but was not negligent in bringing about the forbidden event. ${ }^{10}$ Therefore, cases which speak of a defence of reasonable mistake of fact are merely considering one branch of this new test of due diligence or all reasonable care.

Dickson J. uses the terms "statutory", "regulatory", "absolute liability" to describe offences which in substance are of a civil nature, and further describes them as not being criminal in any real sense but prohibited in the public interest.11 He gives several examples such as traffic infractions, sales of impure food, violations of liquor laws, and pollution. In the judgment, an article by Professor Sayre is quoted as follows: ${ }^{12}$

... if the offence involves a possible prison penalty, the defendant should not be denied the right of bringing forward affirmative evidence to prove that the violation was the result of no fault on his part.

But further: ${ }^{13}$

9. Supra n. 5 at $363-4$.

10. Supra n. 5 at 366.

11. Supra n. 5 at 357 .

12. Sayre, "Public Welfare Offences" (1933) 33 Colum. L. Rev. 55, at 78.

13. Id. at 82 . 
It is fundamentally unsound to convict a defendant for a crime involving a substantial term of imprisonment without giving him the opportunity to prove that his action was due to an honest and reasonable mistake of fact or that he acted without guilty intent.

This leaves unanswered the question of whether offences with a penalty of a minimal prison sentence would give rise to the new defence.

Dickson J. notes the recommendations made by the Law Reform Commission of Canada to the Federal Minister of Justice in 1976, that: ${ }^{14}$

... an accused should never be convicted of a regulatory offence if he establishes that he acted with due diligence, that is, that he was not negligent.

In the judgment, the new category is reconciled with the decision in $R$. v. Pierce Fisheries by stating that the ratio of Ritchie J. was simply that the Crown did not have to prove mens rea in order to obtain a conviction. Dickson J. further states that Ritchie J. did not foreclose all defences, but rather found that due care had not been taken. The judgment in $R$. v. City of Sault Ste. Marie also distinguishes the Supreme Court of Canada case of Hill v. The Queen:15 since the defendant knew her car had touched the rear of the other vehicle, she knew there had been an "accident" and therefore her mistaken belief as to the extent of the damage did not give rise to a defence of reasonable mistake of fact, that is, a state of facts which, if true, would have constituted a defence to the charge.

It should be noted that the defence of reasonable mistake of fact, which is allowed by this new category, is quite different from the so-called defense of mistake of fact which arises in relation to offences requiring full mens rea. Where the Crown has to prove mens rea and the defence is mistake, the defendant is in fact denying an essential ingredient of the Crown's case by alleging that he did not have the necessary mens rea. Therefore, although this situation is often referred to as a defence of reasonable mistake of fact, it is not really a defence nor does it have to be reasonable. The word "reasonable" is merely a caution that if it is not reasonable, it may not be believed. "The principle is that where a circumstance is not known to the actor, his act is not intentional as to that circumstance."16 But under this new middle category, the requirement of reasonableness is a matter of law: $16 \mathrm{a}$

... the doing of the prohibited act prima facie imports the offence, leaving it open to the accused to avoid liability by proving that he took all reasonable care.

In this connection, Dickson J. ${ }^{17}$ quoted Mr. Justice Sheppard in $R$. v. Laroque: ${ }^{18}$

That test has been defined in Bank of New South Wales v. Piper [1897] A.C. 383 at pp. 389-90 as follows: 'On the other hand, the absence of mens rea really consists in an honest and reasonable belief entertained by the accused of the existance of facts which, if true, would make the act charged against him innocent.'

But this formulation is not valid because in criminal law the absence of mens rea does not necessarily consist in a belief which must be reasonable. In the recent rape case of $R$. v. Morgan, ${ }^{19}$ the House of Lords held that if the accused believed that the woman was consenting, even

14. Supra n. 5 at 370.

15. Hill v. The Queen [1975] 2 S.C.R. 402.

16. Glanville Williams, Criminal Law: The General Part, London, Stevens \& Sons Ltd., 1961, at 140.

16a. id.

17. Supra n. 5 at 370.

18. $R$. v. Laroque (1958), 120 C.C.C. 246, at 247 (B.C.C.A.).

19. $R$. v. Morgan [1976] A.C. 182 (H.L.). 
though his belief was unreasonable, he had negatived the mens rea required for the offence.

\section{Actus Reus}

It is not enough to create criminal responsibility that there are mens rea and an act: the actus must be reus.20

Under the new test formulated by Dickson J., the Crown has the burden of proving the actus reus (beyond a reasonable doubt). In law, the actus reus includes so much of the mental element in the offence as is included in the definition of an act. Glanville Williams ${ }^{21}$ defines an act as having three branches:

1. A willed movement (or omission),

2. Certain surrounding circumstances (including past facts),

3. Certain consequences.

He gives the illustration of the act of shooting:22

.. . but shooting is much more than muscular contraction. It involves the fact that the finger is on the trigger of a gun (concomitant circumstances), and the consequence that a bullet leaves the gun. The act of killing a man by shooting involves the further consequence that the bullet enters the victim's body and kills him.

Discussion of mens rea is premature until it is established that the accused is responsible for all the physical ingredients that make up the actus reus. It will therefore be a negation of actus reus if the prohibited action was the result of an "Act of God" or of some other supervening factor that was completely outside the control of the accused, such as acts of malfeasors not in the employ of the accused, or acts of employees of an accused done outside the scope of their employment. Control is essential in determining whether a person or municipality has committed the actus reus of an offence. ${ }^{23}$

The prohibited act would, in my opinion, be committed by those ... who are in a position to exercise continued control of this activity ... but fail to do so.

There are different tests for "control" depending on the wording of the charge. To show "discharging", the Crown must show direct acts of pollution; to show "causing", the Crown must show an active undertaking of something which the defendant was in a position to control and which results in pollution; to show "permitting", the Crown must show the defendant's failure to prevent something which it ought to have foreseen. Since control goes to actus reus, even in an offence of absolute liability the defendant can avoid conviction by showing lack of control.

\section{Analysis of Actus Reus in Reported Cases}

Dickson J. refers ${ }^{24}$ to Professor Jobson's article, "Far from Clear," 25 where Jobson discussed a series of recent cases arising under s. 32(1) of the Ontario Water Resources Act. Jobson says the cases: 26

... openly acknowledged a defence based on lack of fault or neglect: these cases require

20. Supra n. 16 at 17.

21. Supra n. 16 at 16.

22. Id.

23. Supra n. 5 at 376.

24. Supra n. 5 at 370.

25. Jobson, "Far From Clear" (1975) 18 C.L.O. 294.

26. Id. 
proof of the actus reus but then permit the accused to show that he was without fault or had no opportunity to prevent the harm.

Dickson $J$. then refers in particular to $R$. v. Industrial Tankers, ${ }^{27}$ a decision of the Ontario County Court, and states that the burden was placed on the Crown to prove lack of reasonable care. It is submitted that the Ontario County Court merely determined that the defendant was in control such that it could be said to have committed the actus reus. Finding control, the court imposed absolute liability and therefore the court did not allow a defence of reasonable care.

Dickson J. also refers to $R$. v. Sheridan, ${ }^{28}$ where the manager of a mining company was personally charged under s. 32(1) of the Water Resources Act. On a trial de novo, Vannini, Dist. Ct. J., convicted Sheridan of discharging a contaminant into a body of water. After thorough examination, the court found that the defendant was in full charge and assumed all responsibility on behalf of the company, and therefore had the power and authority to control the effluent. Once control was established, the only defence the court considered was whether the defendant was entitled to statutory immunity under s. 32(5) of the Act, in that sewage work was constructed and maintained at the direction of the Commission. The court did not consider lack of fault in determining guilt; fault only went to sentencing.

We therefore respectfully disagree with Dickson J. with regard to $R$. v. Sheridan and $R$. v. Industrial Tankers when he said that "the burden was placed on the Crown to prove lack of reasonable care." In these two cases, the Crown never had the burden to prove control, which went to actus reus.

In $R$. v. Cherokee, ${ }^{29}$ Greco, Prov. J., quotes Sprague J. in $R$. v. Industrial Tankers:

To succeed, the Crown must prove that the pollution was put in the water as a result of an act or omission by the accused or one of its employees which the accused had the power and authority to prevent, and could have prevented, but did not prevent.

He also cites $R$. v. Barrie: ${ }^{30}$

All that is necessary is for the Crown to show that the accused committed the prohibited act and that would be sufficient. The Crown need only prove that the pollution was put into the water as a result of an act or omission by the accused or one of its employees which the accused had the power and authority to prevent but did not prevent.

And Magistrate Baxter, as he then was, in R. v. Matspeck: ${ }^{31}$

I must, therefore, conclude that in order to convict under this statute I must find in the defendants the authority to prevent what actually did take place.

He then stated that these authorities define the law of the Province.

It is interesting that Professor Jobson in his article states that in $R$. v. Cherokee, "Presumably the court did not mean to exclude reasonable care as a consideration in this type of case." 32 This statement may perhaps be explained by Grece Prov. J., where he hints ${ }^{33}$ that the question of mens

27. R. v. Industrial Tankers Ltd. [1968] 4 C.C.C. 81 (Ont. Co. Ct.).

28. $R$. v. Sheridan (1972) 10 C.C.C. 545 (Ont. Dist. Ct.).

29. Supra n. 6.

30. $R$. v. Barrie (1971) 13 Crim. L.Q. 371 (Ont. Prov. Ct., Crim. Div., Roebuck, Prov. Ct. J.).

31. R. v. Matspeck (1965) 8 Crim. L.Q. 455 at 460 (Ont. Mag. Ct., Town of Coberg, R. B. Baxter).

32. Supra n. 25 at 300.

33. Supra n. 6 at 605. 
rea with regard to this statute will depend upon the particular facts of each case; but the circumstances which he implies would entitle the defendant to a dismissal are really concerned with power and authority (and therefore control):

It occurs to the court that acts of God, acts of malfeasors not in the employ of the accused, acts of employees of an accused done outside of the scope of their employment, would be examples of such circumstances.

\section{B. Law Reform Commission Report}

In 1974 the Law Reform Commission of Canada published its report Studies on Strict Liability. ${ }^{34}$ The study was composed of three parts: The Size of the Problem, Strict Liability in Practice, and Strict Liability in Law. The magnitude of the problem was pointed up by the Commission as follows: ${ }^{35}$

First, federal laws contain about 20,000 regulatory offences and the laws of the average province about another 20,000 , and of the combined total ninety per cent (90\%) are offences of strict liability. Second, each year there are roughly $1,400,000$ convictions for strict liability offences and roughly 850,000 persons are convicted of them-a conviction a year for one in twenty-five of the population. The problem, quantitatively speaking, is enormous.

Three areas of federal law were investigated in determining the effect of strict liability in practice: misleading advertising, weights and measures, and food and drugs. The Commission concluded that in all areas some degree of fault is in practice required before an offender is prosecuted: ${ }^{36}$

It is still a legal problem, though. For if the law says guilt doesn't depend on fault and practice says it does, we have a divergence between practice and law. This at best produces confusion, at worst hypocrisy. We suggest it is never advisable to tolerate too large a discrepancy between what the law really is in practice and what on paper it purports to be.

The report points out that, given a specific statute, one can never be certain, until a court tells us, whether the offence created is one of strict liability or whether mens rea is required. The result is that much time, effort, and expense is involved in answering this question; each issue may be dealt with by many courts in several provinces before it is finally settled by the Supreme Court of Canada. Even then, that court offers no rationale which will aid in predicting outcome. As the law stands, like cases are not treated alike and cases that are significantly different are treated alike, because the law does not distinguish between defendants who took all reasonable care and those who did not. This is not satisfactory, because "Where mystery begins, . . . justice ends."37

\section{Statutory Defence of All Reasonable Care}

Dickson J. in the case under discussion cited The Highway Traffic Act, R.S.A. 1970 , c. 169 , s. 198 , as an example of a defence of reasonable care provided by statute. It should be noted, however, that this Act was repealed and substituted in 1975 by two acts: The Highway Traffic Act, S.A. 1975 (2nd session, c. 56), and The Motor Vehicle Administration Act, S.A. 1975 (2nd session, c. 68). Typical offences dealt with under the new Highway Traffic Act include:

34. Supre n. 2.

35. Supra n. 2.

36. Supra n. 2 at 10.

37. Supra n. 2 at 37. 
8. 51-speed appropriate to circumstances

8. 52-standard maximum speed

8. 53-posted speed limits

s. 54-speed in school and playground zones.

Typical offences dealt with under The Motor Vehicle Administration Act include:

s. 24-possession of licence

8. 25-misuse of licence

8. 27-drivers to be qualified

8. 29-learner to be accompanied

8. 31-production of licence

s. 33-failure to produce licence

8. 71-permitting operation of an uninsured motor vehicle.

The statutory defence noted by Dickson J. was imported only into the new Highway Traffic Act as 8. 150:

150. Where a person is charged with an offence under this Act, if the judge trying the case is of the opinion that the offence

(a) was committed wholly by accident or misadventure and without negligence, and

(b) could not by the exercise of reasonable care or precaution have been avoided,

the judge may dismiss the charge.

Therefore, the statutory defence of reasonable care has been and is available for speed-related offences but has not been available for licensing offences since 1975. A search of the Alberta Statute Citators from 1970 to 1978 reveals that this section has never been mentioned in any reported decisions of an Alberta court. It is interesting to note that Estey J., in $R$. v. Hickey, ${ }^{38}$ stated that there are no reported cases where a defence. of reasonable mistake of fact has been recognized by the Australian courts in proceedings under speed-regulation statutes. It should be noted also that the Alberta statute demands a higher standard than the new middle ground because of the conjunctive requirements of "wholly by accident" and "could not have been avoided by exercise of reasonable care."

\section{THE AUSTRALIAN DEVELOPMENT}

A discussion of the middle ground of liability would not be complete without tracing its development in Australia, where for many years the defence of mistake of fact has been allowed for a wide variety of offences. Dickson J. in R. v. City of Sault Ste. Marie referred to several Australian decisions and to the seminal English case of Sherras v. De Rutzen ${ }^{39}$ in formulating the defence of all reasonable care.

The basis of the Australian law and now of the Canadian law, is Wright J.'s dictum in Sherras v. De Rutzen:

There is a presumption that mens rea, an evil intention, or a knowledge of the wrongfulness of the act, is an essential ingredient in every offence; but that presumption is liable to be displaced either by the words of the statute creating the offence or by the subject-matter with which it deals, and both must be considered ... the principal classes of exceptions may perhaps be reduced to three. One is a class of acts which ... . are not criminal in any real sense, but are acts which in the public interest are prohibited under a penalty. ... Another class comprehends some, and perhaps all,

38. R. v. Hickey (1976) 29 C.C.C. (2d) at 29 (Ont. Div. Ct.).

39. Sherras v. De Rutzen (1895) 1 Q.B. 918. 
public nuisances. . . L Lastly, there may be cases in which, although the proceeding is criminal in form, it is really only a summary mode of enforcing a civil right. . . . But, except in such cases as these, there must in general be guilty knowledge on the part of the defendant, or of some one whom he has put in his place to act for him, generally, or in the particular matter, in order to constitute an offence.

This dictum is the guide most frequently relied upon by the High Court of Australia in determining whether the offence in question requires full mens rea. (Dickson J. states that the offence charged in Sault Ste. Marie comes within the first class of exceptions.) If the offence falls within one of the exceptions, "absolute" liability may be imposed or there may be a defence available ("strict" liability).

Although there were earlier indications of the Australian High Court's acceptance of a defence of reasonable mistake of fact, the 1948 decision in Proudman v. Dayman ${ }^{40}$ is most often referred to in later judgments. In that case, Dixon J. stated in obiter that unless from the statute or its subject matter a contrary intention appears, honest and reasonable mistake is probably a ground of exculpation:41

There may be no longer any presumption that mens rea, in the sense of a specific state of mind, whether of motive, intention, knowledge or advertence, is an ingredient in an offence created by a modern statute; but to concede that the weakening of the older understanding of the rule of interpretation has left us with no prima facie presumption that some mental element is implied in the definition of any new statutory offence does not mean that the rule that honest and reasonable mistake is prima facie admissible as an exculpation has lost its application also.

Unfortunately, Dixon J. did not give any indication of the "subject matter" which might give rise to absolute liability.

Many of the later Australian decisions where a defence of reasonable mistake of fact was recognized dealt with offences similar in nature to those codified in The Motor Vehicle Administration Act, S.A. 1975 (2nd session, c. 56). However, it is arguable that the Australian decisions have allowed the defence for statutory offences in all three categories described by Wright J. in Sherras v. De Rutzen. Colin Howard 42 takes the position that the High Court of Australia has consistently imposed absolute liability for offences in the third class of exception set out in Sherras v. De Rutzen, those offences in respect of civil rights. However, it is submitted that these decisions can be explained on other grounds and that there is no indication that the High Court of Australia is reluctant to allow the defence for any certain class of offences.

The 1968 judgment of the High Court in Ianella v. French ${ }^{43}$ is illustrative of problems which can arise where mistake of fact may be a defence. The five judges, in obiter, discussed whether the mistake was one of fact or of law, and came to different conclusions on the point, with one judge drawing the distinction that it was a mistake of fact caused by a mistake of law.

\section{APPLICATION}

\section{A. Highway Traffic}

Sub-section 27(1) of the Motor Vehicle Administration Act, S.A. 1975, c. 68, states: "No person shall permit anyone who is not the holder of an

40. Proudman v. Dayman (1941) C.L.R. 536.

41. Id. at 541 .

42. Howard, "Strict Responsibility in the High Court of Australia", 76 L.Q.R. 547.

43. Iannella v. French (1968) 119 C.L.R. 84. 
operator's licence to drive a motor vehicle." This is roughly comparable to 8. 30 of the Road Traffic Act 1934-1939 (S.A.) which was at issue in Proudman v. Dayman (the seminal Australian case on the defence of reasonable care). This section provided:

Any person who ... drives a motor vehicle on any road without being the holder of a licence for the time being in force, or employs or permits any person not being the holder of such a licence to drive a motor vehicle on any road shall be guilty of an offence.

Applying Dickson's new test, we shall attempt to predict whether this offence will be construed as being within the new second category where a defence of honest and reasonable mistake of fact or due diligence is available.

Our analysis begins by noting that this cannot be an offence that is criminal in the true sense because it is provincially created. What is the subject matter dealt with in this offence? It is common knowledge that licences are granted only after competence is proved by means of a test and are revoked or suspended after proven incompetence. It is a matter of great public concern that only competent drivers drive, and that responsible persons do not allow unlicenced persons to operate a motor vehicle. Licencing offences are undoubtedly public welfare offences enacted in the best interests of public safety. We conclude, therefore, that there is no presumption of a full mens rea. Having reached this conclusion, our next step is to determine whether the offence is one of strict rather than absolute liability. The present case concerns the interpretation of the word "permit." That word is troublesome because it does not clearly denote either full mens rea or absolute liability. Dickson J. concluded that the words such as "permit" and "cause" fit much better into an offence of strict liability. Since s. 27(1) creates a public welfare offence, without a clear indication that liability is absolute, and without any words such as "knowingly" or "wilfully," application of the criteria which Dickson J. outlined places the offence in the second category, an offence of strict liability.

In the decision of Belzil D.C.J. in R. v. Edmund McGilvery, ${ }^{44}$ the statutory offence created by s. 71(3)(a) of The Motor Vehicle Administration Act was construed to be one of strict liability. The section creates the offence of being a registered owner who permits an uninsured automobile to be operated on a highway.

\section{B. Wildlife Protection}

Enforcement of wildlife hunting regulations has given rise to the question of whether absolute liability should be imposed. Game Hunting Regulation 24(1) made pursuant to The Wildlife Act, R.S.A. 1970, c. 391, provides:

24(1). No person shall hunt or have in his possession a male mountain sheep over the age of one year with horns smaller than $4 / 5$ curl.

The relevant section of the Act reads:

No person shall be in possession of any wildlife unless expressly permitted by this Act, the regulations or by The Fur Farms Act or the regulations thereunder.

A problem arises in determining what constitutes a $4 / 5$ curl. The regulations say: (a) where a straight line drawn from the front base of the horn to the tip of the horn passes in front of the eye or eye socket, the 
horn is a 4/5 curl, and (b) where a straight line drawn from the front base of the horn to the tip of the horn passes through any part of or behind the eye or eye socket, the horn is less than a $4 / 5$ curl. This measurement is taken after the animal is dead and the cape is separated from the skull. Of necessity, the hunter in the field uses a different measurement. Two recent Alberta cases have considered this section. In $R$. v. Oyer, ${ }^{45}$ the judge stated that mens rea was immaterial, but furthermore the animal was very carelessly shot as he did not think either the accused or the guide had a good view of the animal before shooting. In $R$. v. Edwards and Verhaeghe, 46 Morrow J.A. could not really consider whether there was a defence of all reasonable care because it was a stated case. He, however, voiced his misgivings:

I feel that I should observe that in reaching my conclusion it has not been without certain misgivings. While the statute places the burden of proof on an accused person the regulations in many respects are almost unintelligible. Emerging from the facts in the present appeal for example is the picture of a hunter being placed in the position where depending on from what position or angle he may be shooting the horns may appear smaller than a $4 / 5$ curl while from another angle they may be larger. Regulations that place a hunter in such a position can only be described as setting a trap for the hunter.

This is provincial legislation and therefore is not criminal in the true sense. Secondly, the subject-matter is conservation and protection of wildlife; the regulation is intended to protect the population of mature rams. Clearly, it is a public welfare offence, in the interests of the public. Therefore, there is no presumption of full mens rea. As a public welfare offence, it is prima facie in the second category.

Has the Legislature made it clear that absolute liability is to be imposed on proof of the proscribed act? The language is "no person shall". The identical words were contained in s. 3(1)(b) of the Lobster Fishery Regulations, P.C. 1963-745, SOR/63-173, the subsection that was considered by the Supreme Court of Canada in the Pierce Fisheries ${ }^{47}$ case. We have the authority of Dickson J. and the unanimous Supreme Court that the ratio of Pierce Fisheries was that the Crown did not have to prove mens rea in order to obtain a conviction. Therefore, we conclude that by these words the Legislature has not clearly indicated its intention that guilt follows proof of the actus reus.

Regulations under the Act provide for the designation of any species of big game and periods of open seasons for different wildlife. Under s. 102, the onus of proof is on the hunter to show that the game was lawfully taken, procured, or kept. The scheme of the Act is to regulate hunting and to establish standards in respect of trophy big game. Furthermore, when the regulations are so unfair if enforced absolutely that Morrow J. refers to them as "setting a trap for the hunter", perhaps a consideration of possible disrespect for the law engendered by such an interpretation would lead to allowing a defence of all reasonable care.

It is concluded that if the Alberta Court of Appeal had to classify this offence with all the facts before it rather than just a stated case, it would find this an offence of strict, rather than absolute, liability. 


\section{Corporations as Defendant: Implications}

In the penultimate paragraph of his judgment, Dickson J. comments upon the defence of reasonable care in the context of a corporation. He states that the doctrine of respondeat superior has no application. The defendant must prove its due diligence, not that of its employees. If a corporation is charged because of an act of an employee committed in the course of his employment, the issues will be whether the act took place under the defendant's direction or with its approval and whether the defendant exercised all reasonable care by setting up a system to prevent offences taking place and by ensuring that the system was functioning properly. For a corporation to take advantage of the new defence, it will have to demonstrate that all reasonable care was taken by those who are the "directing mind and will" of the corporation. To illustrate what this formulation entails in terms of corporate responsibility, Mr. Justice Dickson refers to the 1972 House of Lords decision in Tesco Supermarkets Ltd. v. Nattrass. ${ }^{48}$

Because regulatory offences very often involve corporations, it is useful to examine the decision in Tesco.

The facts of Tesco were not complex. Tesco Supermarkets, a chain of 800 stores, was promoting Radiant soap at $2 \mathrm{~s} 11 \mathrm{p}$ rather than at its regular price of $3 \mathrm{~s} 11 \mathrm{p}$. A large poster in the store window advertised the sale. However, one store ran out of sale packages marked with the reduced price. A store clerk put boxes marked at the regular price in the display bin but did not tell the store manager what she had done, nor did he check, notwithstanding the fact that it was his explicit duty to check on promotions. But he wrote in his book "all special offers-0.K.". An old age pensioner came to the store and tried to buy Radiant soap at the advertised price; he was forced to pay the regular price. A complaint followed and a conviction was registered by a magistrate, and sustained by the Divisional Court. The House of Lords reversed the conviction. The company was held to have met its burden of showing due diligence because it had set up a system of supervision and inspection. The store manager's negligence was not held to be a breach of the company's duty.

Each of the five judges who sat on this appeal gave a separate speech. Lord Reid stated that it was a question of law whether a person doing a particular thing was to be regarded as the company or merely as an agent or servant of the company. Normally the Board of Directors would act as the company: 49

But the Board of Directors may delegate some part of their functions of management giving to their delegate full discretion to act independently of instructions from them.

Such a delegate, having been given full discretion, would be the company for any acts within the scope of the delegation of discretion. But on these facts, Lord Reid finds no such delegation of discretion, merely a chain of command. Tesco, because it had demonstrated a comprehensive system of inspection and supervision, was held to be without fault. Lord Reid felt that magistrates could see through any "paper system" of supervision presented as a defence. But if the defence shows by policy directives and evidence of executives that the corporation has a system, the burden shifts to the Crown to show that the system does not function in practice. 
In the result all five judges agreed that Tesco should not be held liable. Lord Reid and Lord Morris did not mention the possibility that the store manager or the shop clerk or both could be liable. Lords Dilhorne, Pearson and Diplock raised the question but specifically did not decide it. Lord Dilhorne suggested both might be liable although the separate actions of neither party could be said to constitute the complete offence. This result leaves one with a feeling of unfairness. To quote Lord Denning: 50

The master takes the benefit and should bear the burden. The wages are fixed on that basis. If the servant is to bear the risk, his wages ought to be increased to cover it.

If neither employee is liable and the company is not liable, then an offence against the public welfare has been committed and no one is held responsible. It would seem that this is the place for corporate liability.

Lord Reid felt that the courts could pierce a "paper system." But it is clear that a large organization which can put several layers of management between the Board of Directors and its line staff will more easily be able to show that no particular person has been delegated "full discretion".

\section{CONCLUSION}

The potential difficulty of holding corporations liable for breach of public safety regulations can be illustrated by incidents such as the evacuation of the Edmonton suburb of Mill Woods in March of 1979. Before the Supreme Court of Canada's decision in the Sault Ste. Marie case, proof of the breach of a regulation led to conviction. Now it merely shifts the onus to the defendant to show that on a balance of probabilities it had taken all reasonable care. Where 25 corporations own the pipeline and have delegated the duty of operator to one corporation, it is much more likely that a corporation could escape responsibility by demonstrating that the employee who breached the regulation is not the company. With 700 pipeline breaks every year in the city of Calgary alone, Albertans need all possible regulatory stringency to fix corporations with liability for their inherently dangerous undertakings. The decision in Sault Ste. Marie with its acceptance of Tesco has made it necessary for the Alberta legislature in enacting public safety legislation to explicitly state that the offences are ones of absolute liability.

Laura DiSanto* Sheila McAllister**

50. Morris v. Ford Motor Co. [1973] 1 Q.B. 792 (C.A.).

* Articling with the firm Ghitter \& Company, Calgary.

** Articling with the firm Ballem, McDill \& MacInnis, Calgary. 